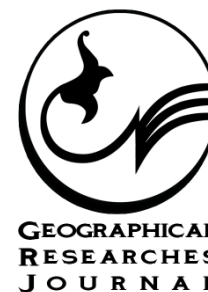

\title{
Assessment and Measurements of Social Capital Status; a Case Study of Zakhiroyeh District Villages
}

\section{ART I C L E I N F O}

\section{Article Type}

Original Research

\section{Authors}

Behmand D. ${ }^{* 1} P h D$
How to cite this article Behmand D. Assessment and Measurements of Social Capital Status; a Case Study of Zakhiroyeh District Villages. Geographical Researches. 2019;34(3):313 322 .

${ }^{1}$ Department of Geography, Payame Noor University, Tehran, Iran

\section{*Correspondence}

Address: Payame Noor University, Firoozabad, Fars, Iran Phone: +98 (71) 38736217

Fax: +98 (71) 38736217

d.behmand@gmail.com

\section{Article History}

Received: April 19, 2019

Accepted: September 7, 2019

ePublished: October 2, 2019

\section{A B S T R A C T}

Introduction and Background Attention to social capital can play an important role in improving the process of planning for rural development, relevant professionals and facilitating the participation of villagers in the better implementation of the program. The present research pursues two main objectives: a) Assessment and measurement of the status of social capital in the villages of Zakheryeh rural districts. B. Determining the extent of the impact of the three main dimensions of social capital (trust, participation and cohesion) on the status of social capital.

Methodology Research method is descriptive-analytical. According to the statistical population (3382 people); the sample size was determined using the Cochran formula which is 345 people. In this research social capital was evaluated using 20 variables in the form of a questionnaire. Descriptive and inferential statistics were used for analysis using T-Test, Spearman and Path Analysis.

Findings Among the research variables, only Social Participation has a direct impact on social capital. The other two variables of research (trust and social cohesion) have direct and indirect effects on social capital.

Conclusion Social participation has a direct impact on social capital ( 0.624 unit). The most favourable status of social capital was related to Mazraeh, Pahn, Cham Koor and Pir Gheyb respectively.

Keywords Social Capital; Social Trust; Social Participation; Social Cohesion; Zakhiroyeh District Villages

\section{I T A T I O N L I N KS}

[Abusamah \& Aref; 2009] People's participation in community development: A case study in a planned ...; [Afrakhteh, et al; 2014] The role of social capital on rural development in Chahar Dandah ...; [Amirantakhaby, et al; 2017] Social capital and sustainability of rural areas in ...; [Amado, et al; 2009] Public Participation in Sustainable Urban ...; [BabaeiAgdam, et al; 2015] A study on partnership of settlement in organization of urban distressed areas with an ...; [Bahrami; 2018] Assessing the impact of social capital on rural development the case of Sanandaj district ...; [Barimani, et al; 2018] Analysis of the relationship between social capital and critical security factors: Border ...; [Barghi \& Zolfaghari; 2018] Explaining status of entrepreneurship indicators and predicting them in rural residences case study: Ravansar ...; [Coleman; 2007] Foundations of social ...; [Dadvar, et al; 2013] Comparative study of social capital on rural development upgrade case study: Godvin Rural District ...; [Ellison, et al; 2011] Connection strategies: Social capital implications of Facebook-enabled ...; [Farahani, et al; 2013] Evaluation of the impact of social capital on the development of rural areas ...; [Ghahhari, et al; 2014] The study of social capital in Zanjan ...; [Hafeznia; 2013] An introduction to the research method in ...; [Heydari Sarban; 2014] The effects of social capital effects the rural areas development case study: ...; [HeydariSarban, et al; 2016] Study and evaluation of the impact of resettlement patterns on social capital changes in ...; [Imani, et al; 2016] Studying and evaluating effects of social capital on life quality in rural ...; [Kakavand, et al; 2009] Comparative assessment of social investment in neighborhoods by AHP method case study: ...; [Larson; 2007] Public trust in the PR industry and Its ...; [Maleki, et al; 2015] Measuring coefficient of development ability of big villages of ...; [Mohammadnia, et al; 2018] To study the interaction between social capital and quality of life; both objective and subjective) ...; [Nyhan; 2000] Changing the Paradigm: Trust and Its role in public sector ...; [Putnam; 2000] Bowling alone: The collapse and revival of American ...; [Sabine; 2004] Trust-Building strategies in inter-Organizational ...; [Safaei Pour \& Rahimi Chamkhani; 2018] Critical analysis of sampling designs in human geography research by focusing on selection bias in ...; [Sharifinia; 2018] Evaluation of social capital in rural settlements case study: Ganj Afrooz ...; [Taleb \& NajafiAsl; 2011] Doctrines of rural participation trend in ...; [ToulabiNejad, et al; 2018] Evaluate the impact of social capital on welfare of rural households case study: District Eastern Miyankoh city ...; [World Bank; 2008] World development report 2008: Agriculture for ...; [Yazdani \& Shams; 2016] The effect of social capital on the environmental behavior of villagers in Marivan City; [Yeganeh , et al; 2017] The effects of social capital in economic diversity ...; 
از مشكلات اساسى در دستيابى به توسعه روستايى است. توسعه

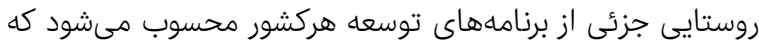

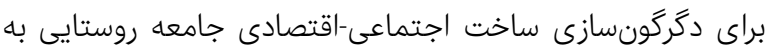

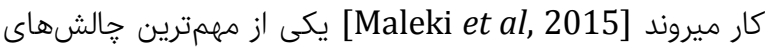

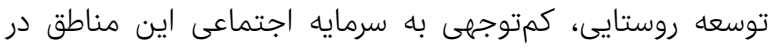

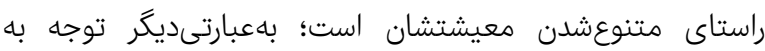

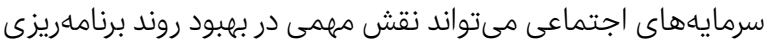

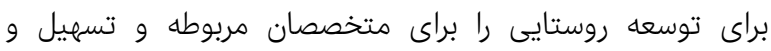

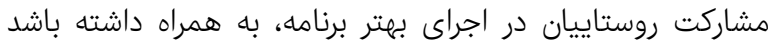

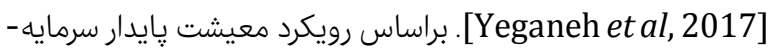
هاى خانوادهها براى بهبود بخشى به شرايط محل زندگى خود

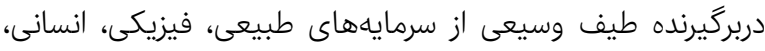

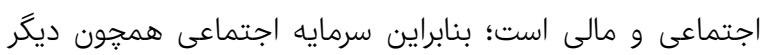

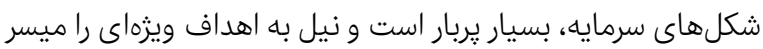

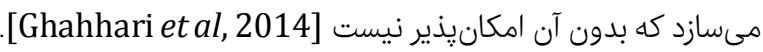

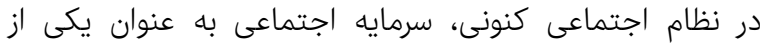

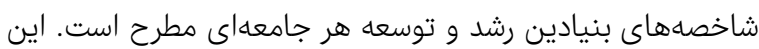
مفهوم حوزههاى متفاوتى از جمله توسعه روستايى، توسعه

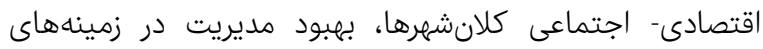
مختلف و سطوح مختلف خرد و كلان و غيره را در بر مى زئيرد.

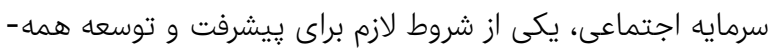

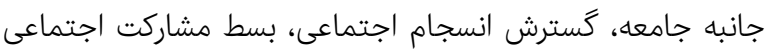

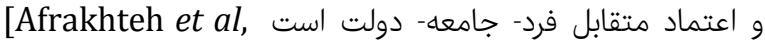

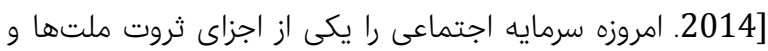

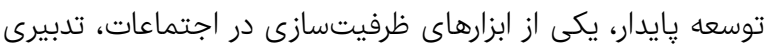

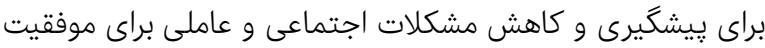

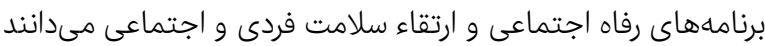
و در ارتباط با توسعه مناطق روستايى سرمايه اجتماعى ابزارى براى

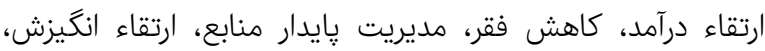

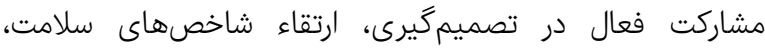

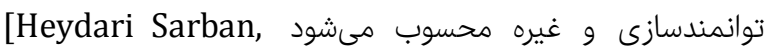

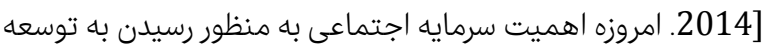

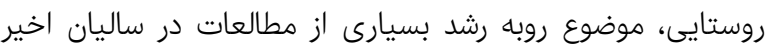

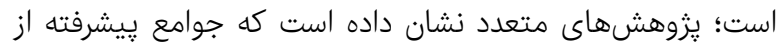

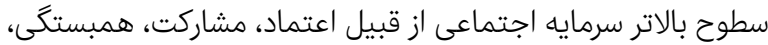

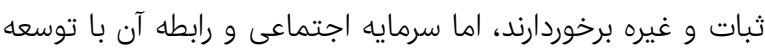
در ايران به طور كامل شناخته نشده است. با توجه به اينكه بيشتر اجنت

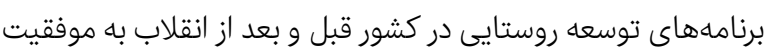
كامل دست نيافتهاند، لزوم توجه به واكاوى ابعاد مختلف اين عدم دوري

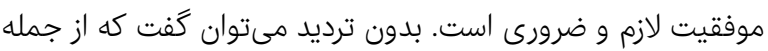

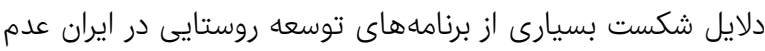

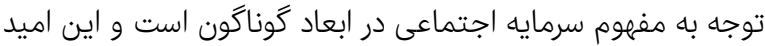

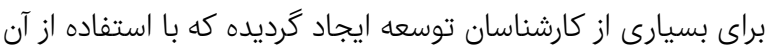

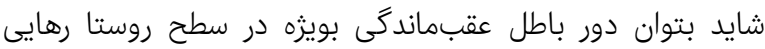

ارزيابى و سنجش وضعيت سرمايه اجتماعى؛ مطالعه موردى روستاهاى دهستان زاخرويه

PhD داداله بهمند

كروه جغرافيا، دانشكاه بِيام نور، تهران، ايران

جكيده

اهداف و زمينهها: توجه به سرمايههاى اجتماعى مىتواند نقش مهمى در بهبود

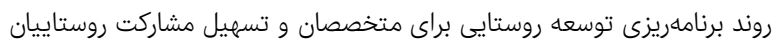

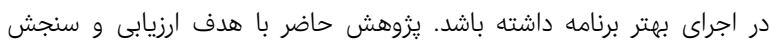

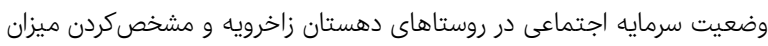
اثركذارى اعتماد، مشاركت و انسجام در وضعيت سرمايه اجتماعى انجام شد. روششناسى: روش انجام اين يزوهش توصيفى-تحليلى است. جمع آورى دادها آنها

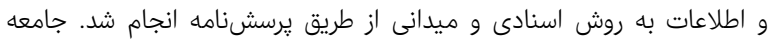

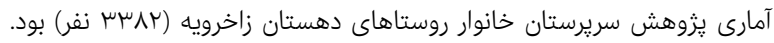

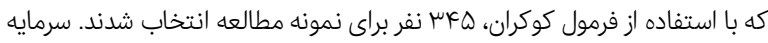

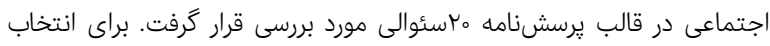

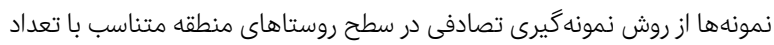

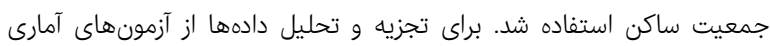

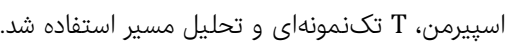

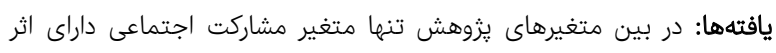

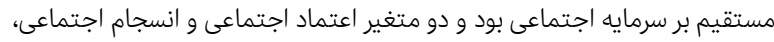
داراى اثرات مستقيم و غيرمستقيم بر سرمايه اجتماعى بودند.

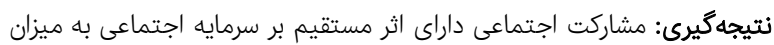

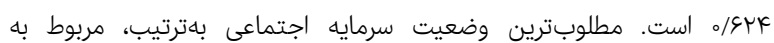
روستاهاى مزرعه بِهن، جمكور و بِيرغيب است.

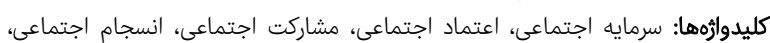

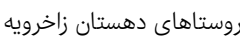

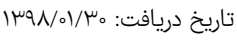

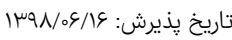

d.behmand@gmail.com : نويسنده مسئول:

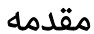

نقش و جايگاه روستاها در فرايندهاى توسعه اقتصادى، اجتماعى مقده و سياسى در مقياس هاى محلى، منطقهاى و بين المللى و رييامدهاى

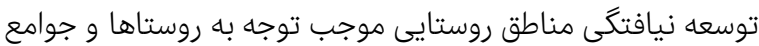

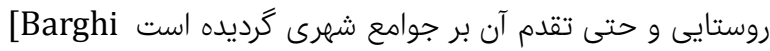

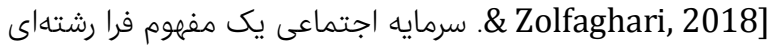
و زمانبر است؛ كه در تحليلها مرتبط با جوامع روستايى مطرحشده سهايه

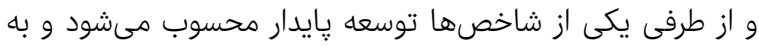

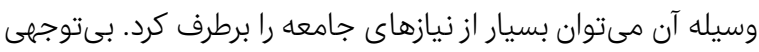

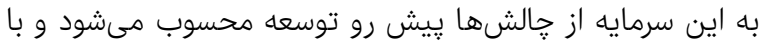
شناخت آن مىتوان برنامهريزهاى را با مشاركت بيشتر مردم تسهيل

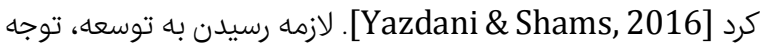

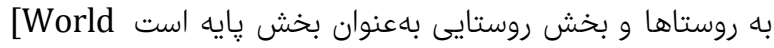

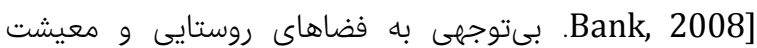

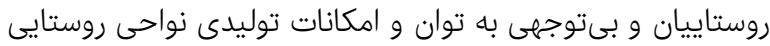


ارزيابى و سنجش وضعيت سرمايه اجتماعى؛ مطالعه موردى روستاهاى دهستان زاخرويه هابـ

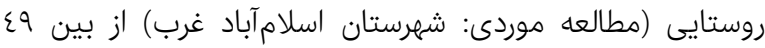
روستا از لحاظ شاخصهاى سرمايه اجتماعى، 0 روستا در سطح

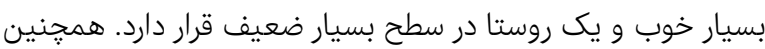
مؤلفه مشاركت اجتماعى (مهمترين مؤلفه سرمايه اجتماعى)

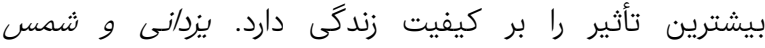
] ضمن استفاده از رويكرد توصيفى- تحليلى و استفاده از يرسشنامه به بررسى اثرات سرمايه اجتماعى بر رفتارهاى زيستمحيطى روستاييان شهرستان رهان مريوان

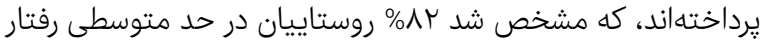

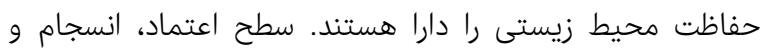

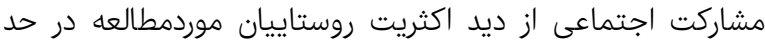

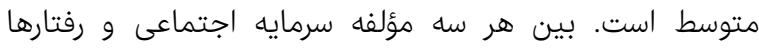
زيستمحيطى روستاييان رابطه مثبت و معنىدار وجود دارد. طولابى مهنى نز/د و همكاران [Toulabi Nejad et al, 2018] با مطالعه اثرات سرمايه اجتماعى بر رفاه خانوارهاى روستاهاى دهستان ميانكوه

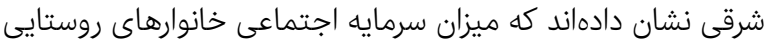

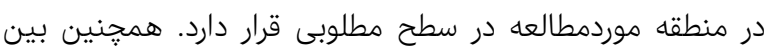

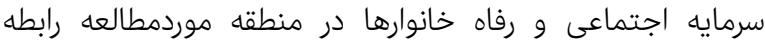
معنادارى وجود دارد و از ميان مؤلفههاى سرمايه اجتماعىى، مشارها داركت

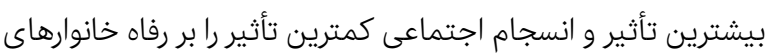

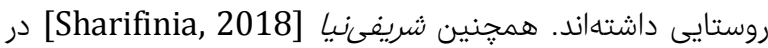

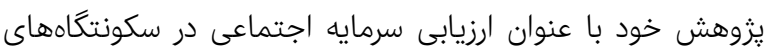

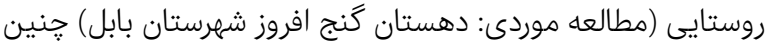
نتيجه مى گيرد كه؛ ميانگين دادههاى سرمايه اجتماعى در دهان دهستان

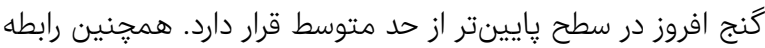

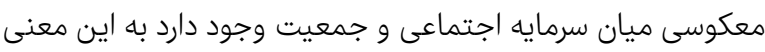

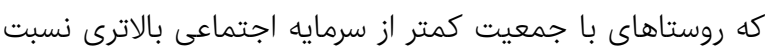
به روستاهاى با جمعيت بيشتر برخوردارند.

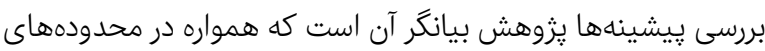
مورد مطالعه اختلاف فراوانى بين روستاها به لحاظ وضعيت سرمايه بيه اجتماعى وجود دارد و در بسيارى از موارد وضعيت كلى سرمايه

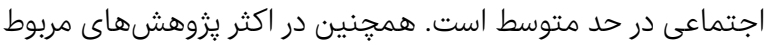

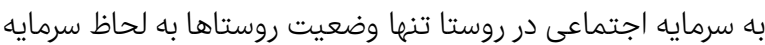

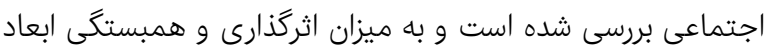

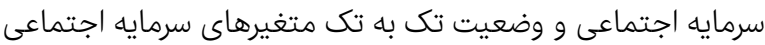

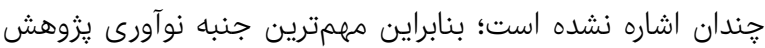
علاوه بر بررسىكردن وضعيت سرمايه اجتماعى و ابعاد آن در سطح

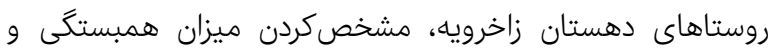

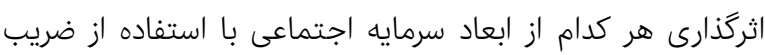
ييرسون و تحليل رگرسيون است.

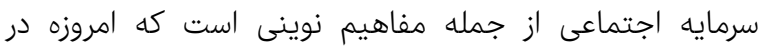
بررسىهاى اقتصادى و اجتماعى جوامع مدرن مطرح گَرديده است. سرمايه اجتماعى نخستين بار در سال 1917 ميلادى توسط هانى هانى

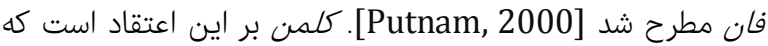

يافت[Dadvar Khani et al, 2013]. علاوه براين، سرمايه اجتماعى، وجود گوناگون سازمان اجتماعى نظير اعتماد، هنجارها و

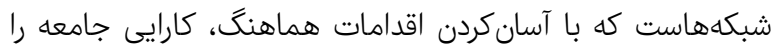

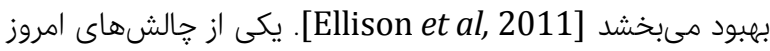

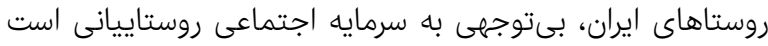

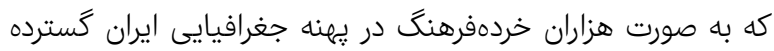

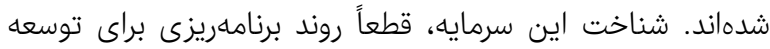
روستايى را براى متخصصان تسهيل مىكند و مشاركت روستاييان

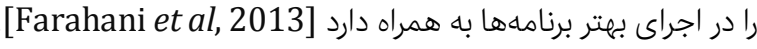
ضرورت اين تحقيق آن است كه در دنياى امروز بدون سرمايه

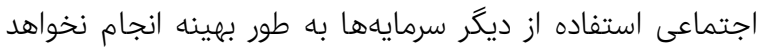

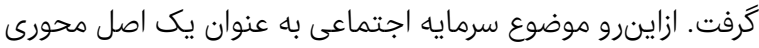
براى دستيابى به توسعه محسوبشده و مديرانى موفق قلمداد

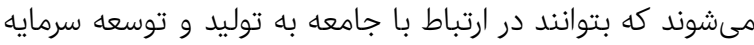

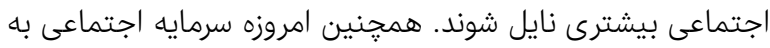
عنوان زيربناى توسعه پايدار، نقشى بسيار مهمتر از سرمايه فيزيكى

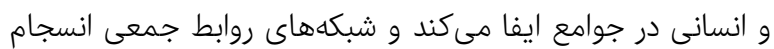

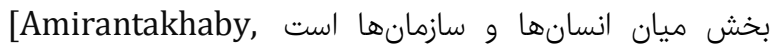

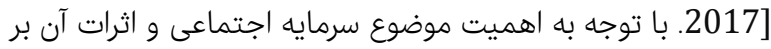

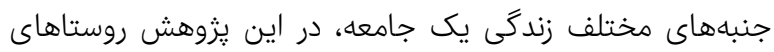

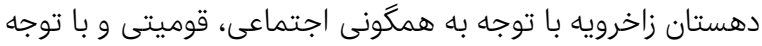

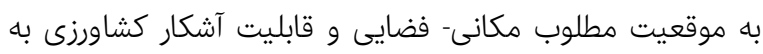

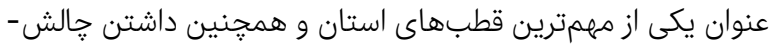

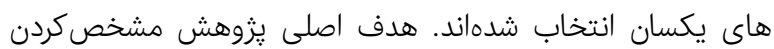

وضعيت سرمايه اجتماعى در روستاهاى دهستان زاخرويه بود.

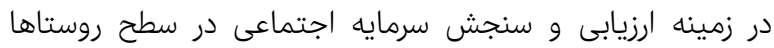

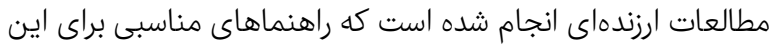

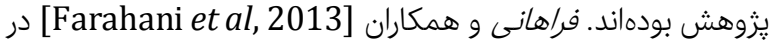
يزوهش خود با عنوان 》ارزيابى نقش سرمايه اجتماعى در توسعه

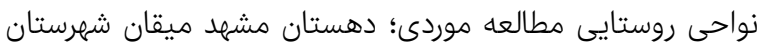

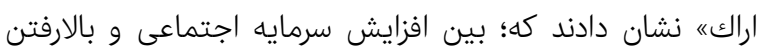

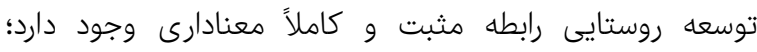

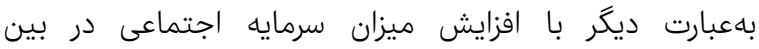

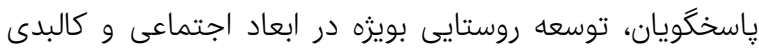

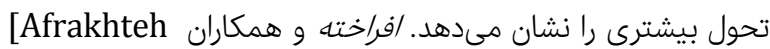

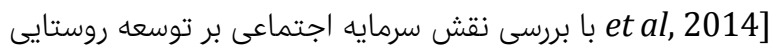

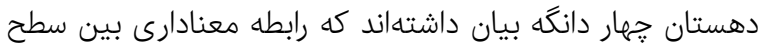

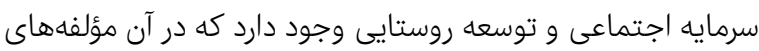

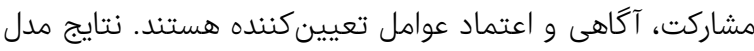
شبكه عصبى نشاندهنده اين است كه متغيرهاى مشاركت، اعتماد

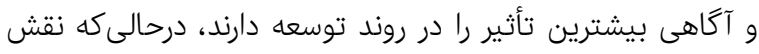

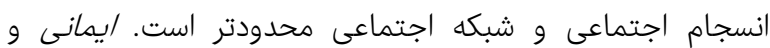

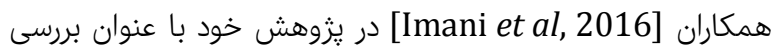

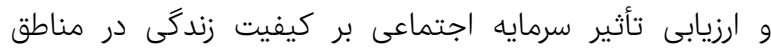


مؤلفههاى اصلى سرمايه اجتماعى محسوب مىشوند Babaei]

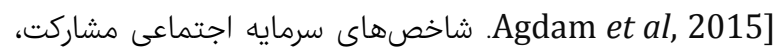
اعتماد و انسجام اجتماعى است[Taleb \& Najafi Asl, 2011].

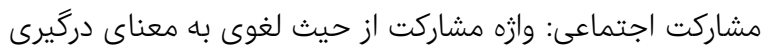

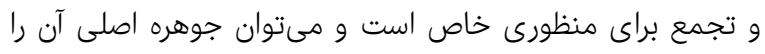

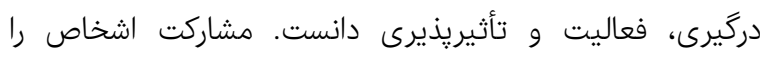

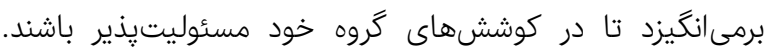

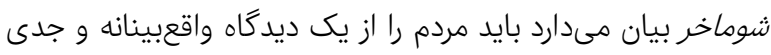

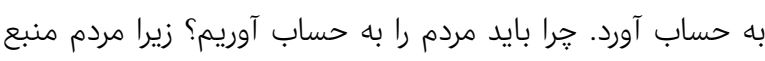
اصلى و نهايى هرگونه ثروتاند؟ اگر مورد غفلت قرار گيرند، اخر آلت آلت

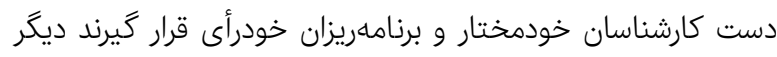
هيج تلاشى ثمر واقعى نخواهد داشت. اين جمله بهخوبى بـان بيانكر

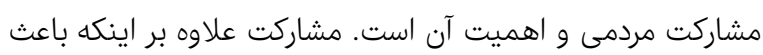

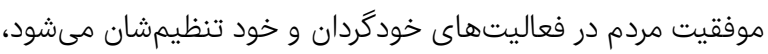
اعتماد، مهارتها و دانش مردم را كه محصول نهايى مشاركت است، مرديت

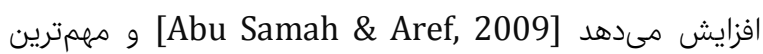
مقوله در فرآيند توسعه و تحول شهرهاى آينده است Amado et]

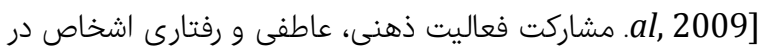

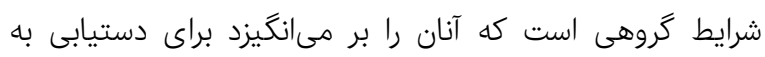

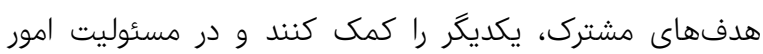

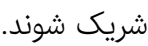
اعتماد اجتماعى: اعتماد اجتماعى به عنوان يكى از مهمترين عناصر

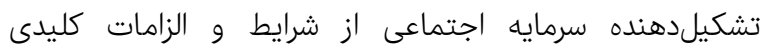

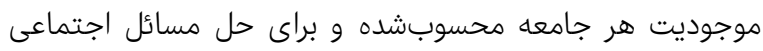

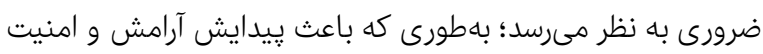

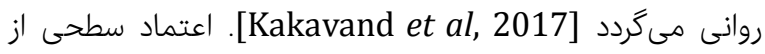

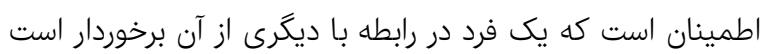

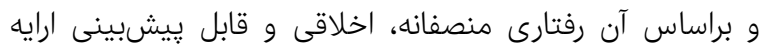

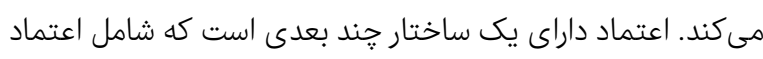
بين فردى، بين دو نفر، گروهى، سازمانى، بين سازمانى، اعندا، اعتماد

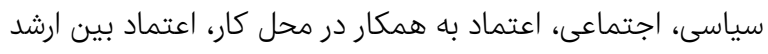

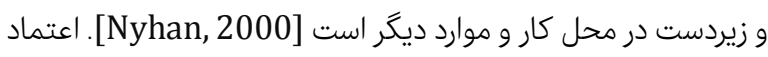

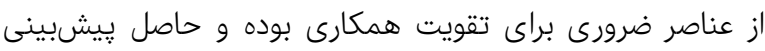

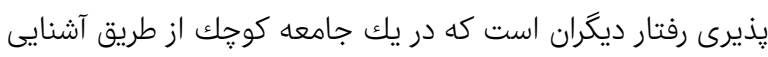

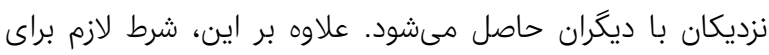

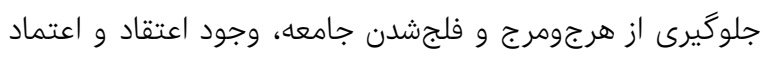

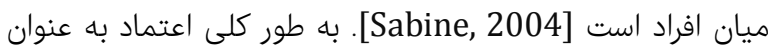
بخشى از واكنش فرد در قبال ديگران و به عنوان بخشى از برهم

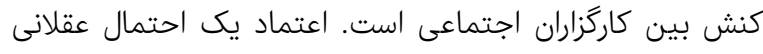

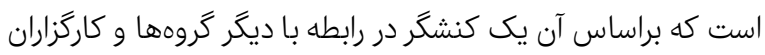

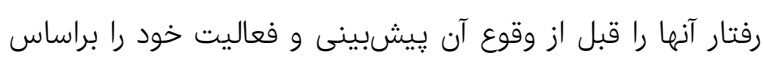

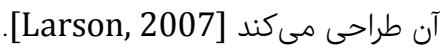

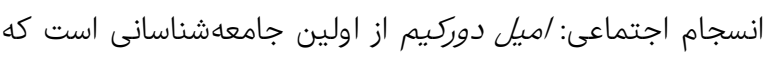

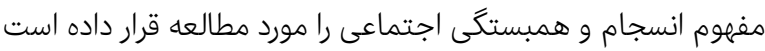

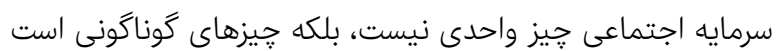

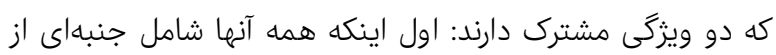

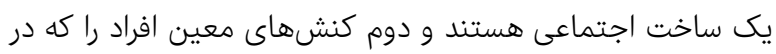

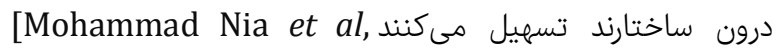

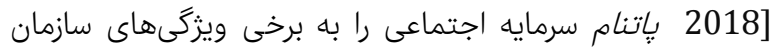
اجتماعى از قبيل شبكههاى اجتماعى، هنجارها و اعتماد نسبت

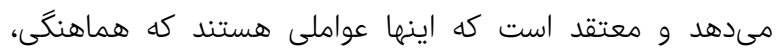

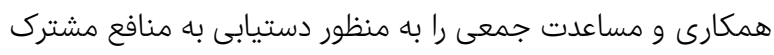
تسهييل مىكند [Jenks \& Jones, 2010]. از نظر فوكوياما به مناعيه سادگى مىتوان سرمايه اجتماعى را به عنوان مجموعه معينى از

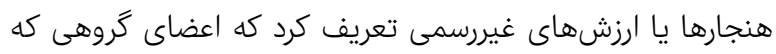
همكارى و تعاون ميانشان مجاز است درن در آن سهيمريم هستند

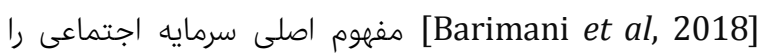
مىتوان در سه كلمه بيان داشت: ارتباطات مهم هستند. با ايجاد

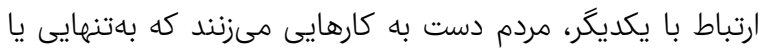
قادر به انجام آن نيستند يا براى انجام آن مشكلات فردان فراوانى خواهند

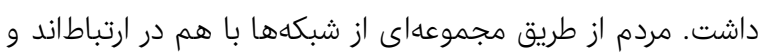

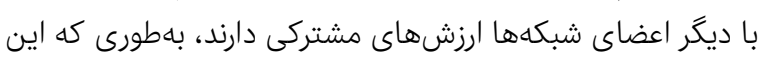
شبكهها منبعى ايجاد مىكنند كه به نظر مى آيد آنها نوعى سرمايه

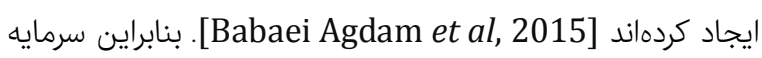
اجتماعى فقط شامل احساسات گرم و عاطفى نيست بلكه گستره

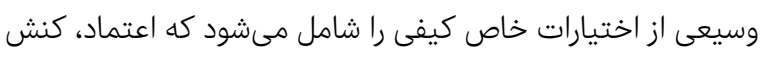

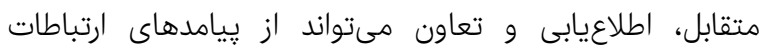

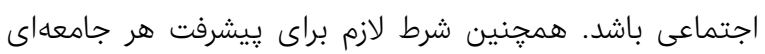

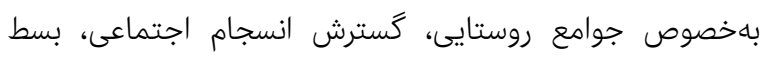

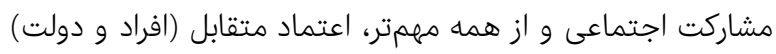
است كه اين سازهها از مؤلفههاى سرمايه اجتماعى به شمار همار مى آيند

[Farahani et al, 2013]

اهميت سرمايه اجتماعى در جوامع روستايى به دليل تأثيراتى است

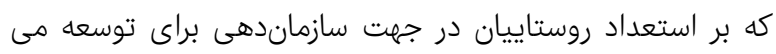

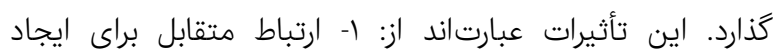

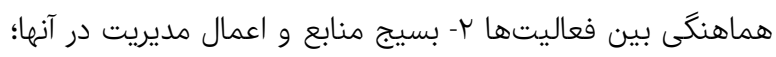

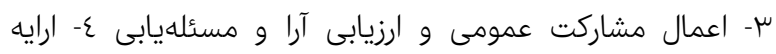
راهكارهاى حل مشكلات. اين جهار كار تأثيراتى است كه سرمايه

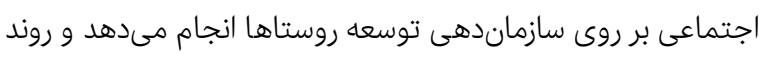
آن در جهت رسيدن به رفاه عمومى جوامع روستايى است رونان

.[Heydari Sarban et al, 2016]

سرمايه اجتماعى داراى ابعاد و مؤلفههاى فراوانى است كه متناسب

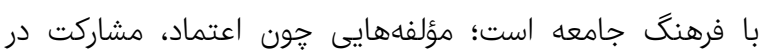

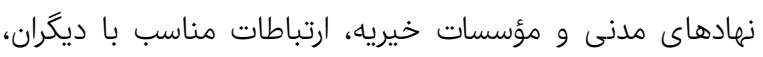

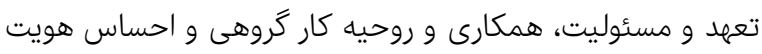

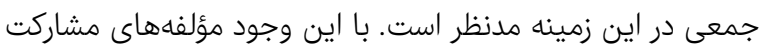

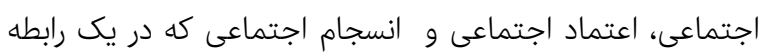

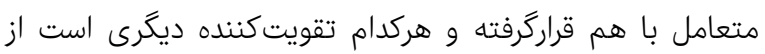




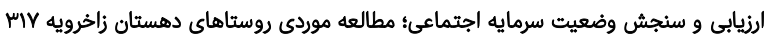

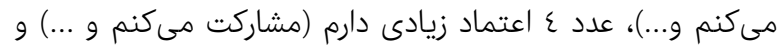

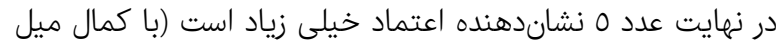

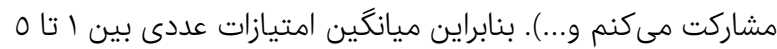

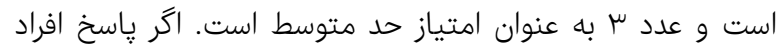

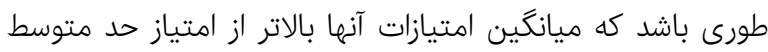

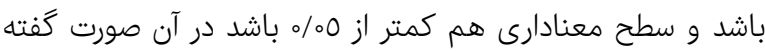

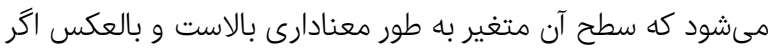

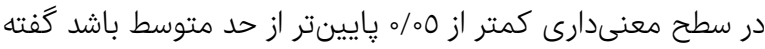
مىشود كه به طور معنادارى سطح متغير بالاتر از حد متوسط است است.

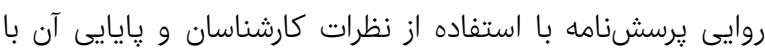

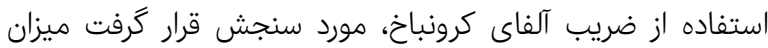

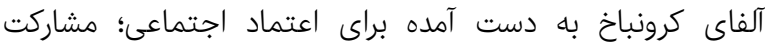

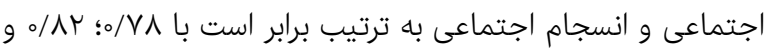

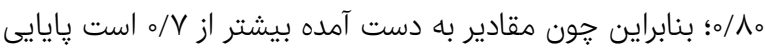

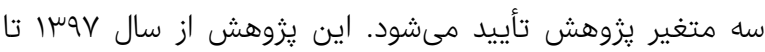

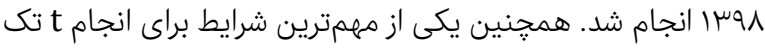

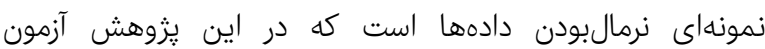
كولموكروف-اسميرنوف نشان داد كه اطلاعات مربوط به محدوده

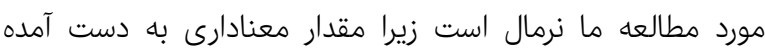

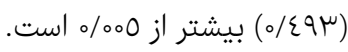

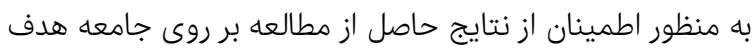

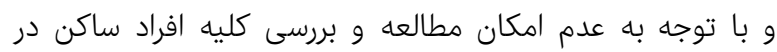
روستاهاى دهستان زاخرويه، اقدام به تعيين نمونه آمارى گرديده

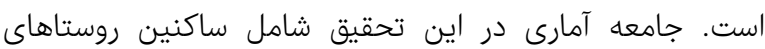

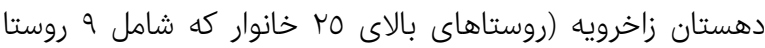

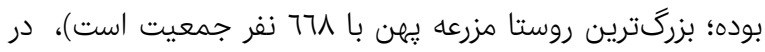

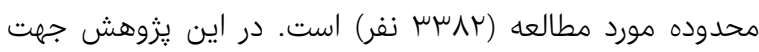

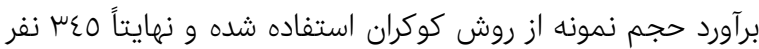

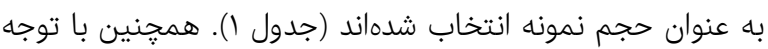

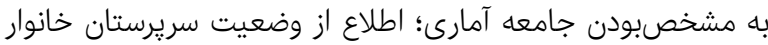

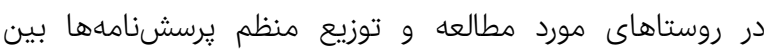

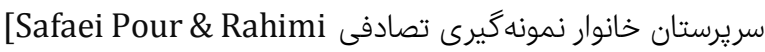

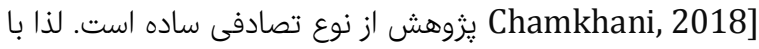

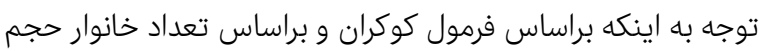

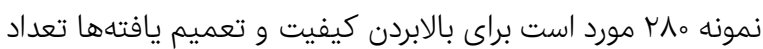

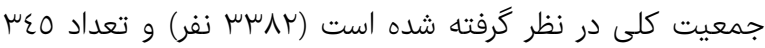

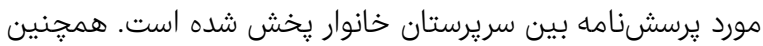

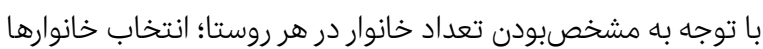
براساس شمارهاى بوده كه به هر خانوار داده شده و كاملاً به صورت

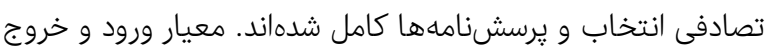

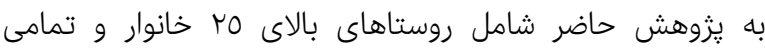

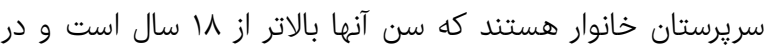

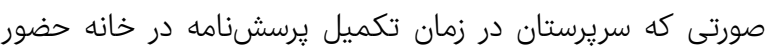

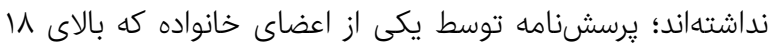

و وجود آن را براى هر جامعهاى لازم مىداند. جاناتان ترنر به نقل از

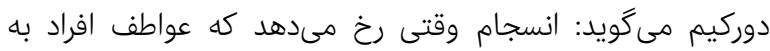

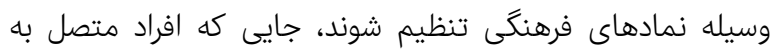

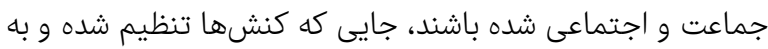

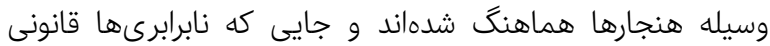
تصور مىشود. با توافق جمعى ميان اعضاء يك جامعه كه حاصل هاصل يذيرش، درونى كردن نظام ارزشى و هنجارى يكى جامعه و وجود

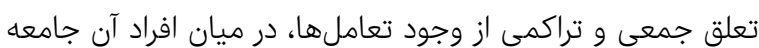

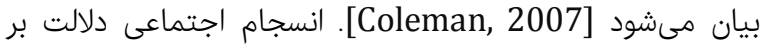
توافق جمعى ميان اعضاى يك جام إمعه دارد. به عبارتى انسجام

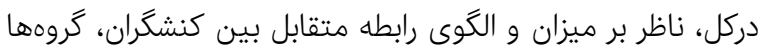

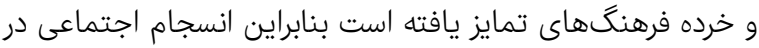

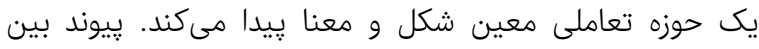
انسجام اجتماعى و مشاركت اجتماعى نيز حائز اهميت است. زئ زيرا

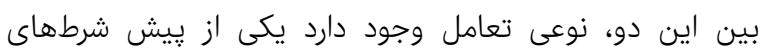

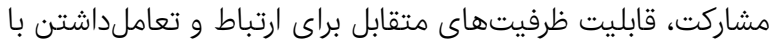

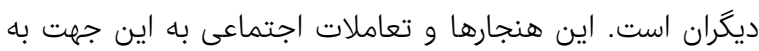
عنوان يك سرمايه و در قالب سرمايه اجتماعى تعريف مى هیى داراى كاركردهاى اقتصادى مهمى در سيستمهاى اجتماعى هستند

.[Bahrami, 2018]

\section{روش}

روش انجام يزوهش براساس هدف، كاربردى و براساس ماهيت و

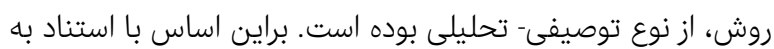
روش توصيفى-تحليلى و بر مبناى مطالعات و بررسىهاى ميدانى و

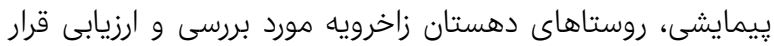

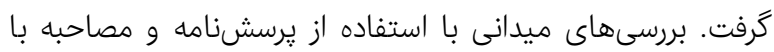

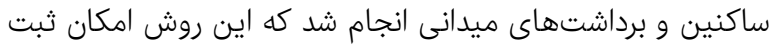

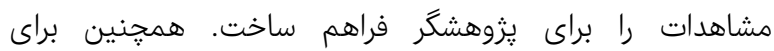
تجزيهوتحليل اطلاعات حاصل از تيرسشنامه، از ابزار آمارى و و كرافيكى EXCEL و نمونهاى و تحليل مسير استفاده شده است.

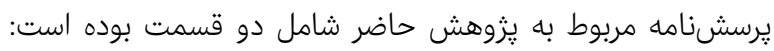

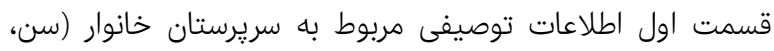
جنس، وضعيت اشتغال و ...) بررسى شده است و در قسمت دوم

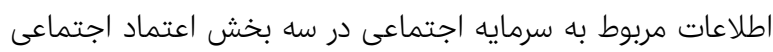

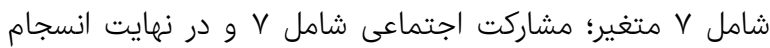

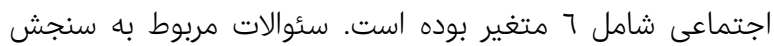

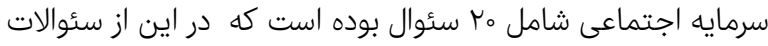

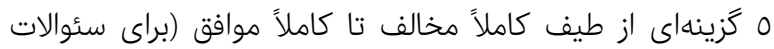
منفى برعكس است) (طيف ليكرت) استفاده شده است. در تحليل آمارى نيز 0 ارزش داده شده است، عدد ا اصلاً اعتماد ندارم (اصلاً

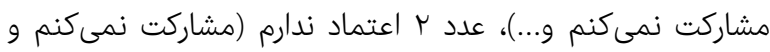
...) ، عدد س اعتمادم در حد متوسط است (در حد متوسط مشاركت 
بنابراين با توجه به نتايج جدول r مشاركت اجتماعى با ميزان بتاى

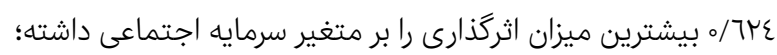

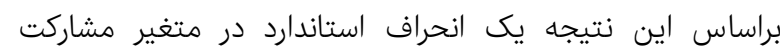

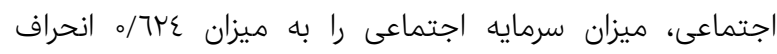

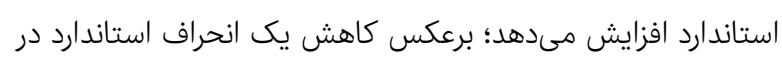

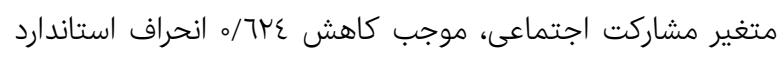

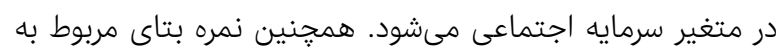

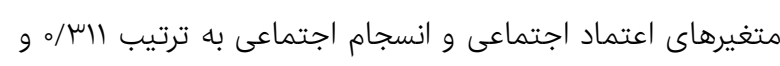

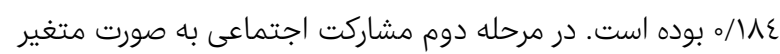

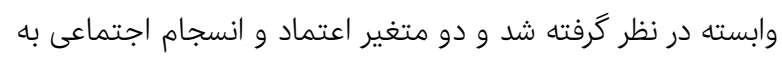

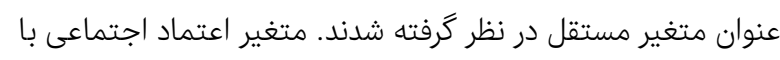

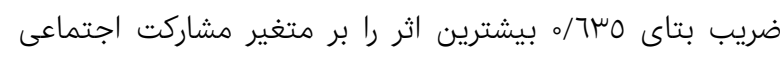

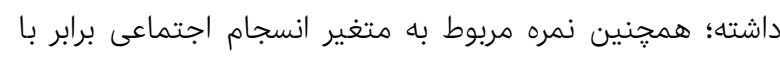

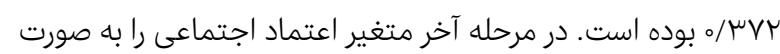

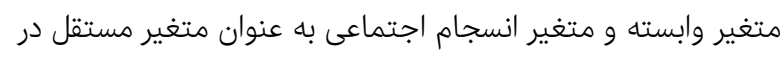

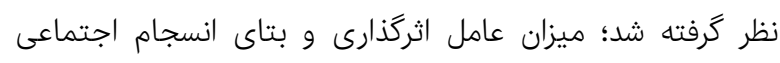
אT/A/ه بوده كه بيشترين اثر را بر اعتماد اجتماعى داشته است.

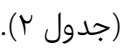

\begin{tabular}{|c|c|c|c|c|c|}
\hline \multicolumn{3}{|c|}{ ضرايب استاندارد شده } & \multicolumn{2}{|c|}{ ضرايب استاندارد نشده } & \multirow{2}{*}{ 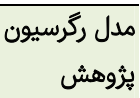 } \\
\hline Sig. & $\mathrm{T}$ & Beta & Std. Error & $\mathrm{B}$ & \\
\hline & & & & \multicolumn{2}{|c|}{$\begin{array}{r}\text { متغير وابسته (سرمايه } \\
\text { اجتماعى) }\end{array}$} \\
\hline o/lkr & $r / Q \wedge \mu$ & & $0 / 101$ & D/TER & (Constant) \\
\hline$\%$ & K/DSY & $\circ / \mu \|$ & $\%$ \% & $\circ / \Lambda Q \mu$ & اجتماعى \\
\hline$\%$ & $1 / 9 V^{\mu}$ & o/GMK & $\circ / 19$ & $\%$ & مشاركت \\
\hline$\%$ & F/VGY & o/MAK & $\% 11$ & $\circ / 109$ & اجتماعى إم \\
\hline & & & \multicolumn{3}{|c|}{ متغير وابسته (مشاركت اجتماعى) } \\
\hline o/rAK & 1/qur & & $\% / 9 k$ & o/løk & (Constant) \\
\hline$\%$ & $10 / \mu_{0} 9$ & ./GHa & $\% 11$ & o/IVe & اجتمادى اعتماد \\
\hline$\%$ & N/9V & $\circ / \mu V r$ &.$\% 18$ & o/TGK & اجتماعى إم \\
\hline & & & \multicolumn{3}{|c|}{ متغير وابسته (اعتماد اجتماعى) } \\
\hline o/lks & s/N.K & & 。/mqY & $k / T \Lambda I$ & (Constant) \\
\hline$\%$ & $q / k V Y$ & ०/А\&Y & $\% \vee Y F$ & $0 / 4 I K$ & اجتماعى إن \\
\hline
\end{tabular}

جمعبندى نتايج تحليل مسير در مراحل مختلف درئ

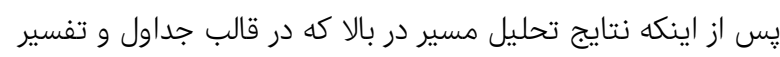

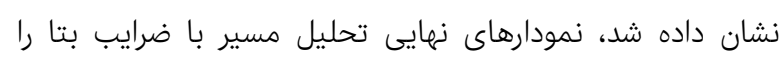

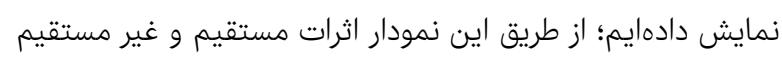

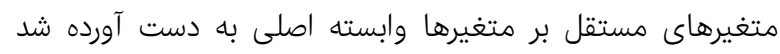

سال بوده تكميل شده است. همجنين در بزوهش حاضر تمام موارد

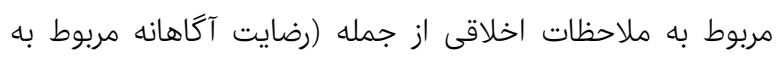

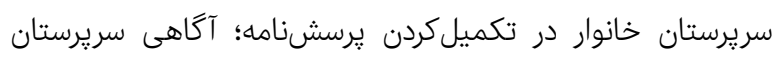

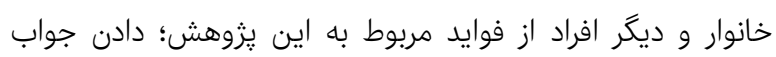

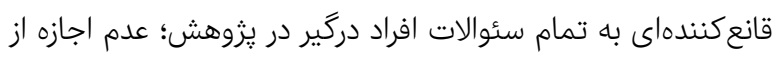

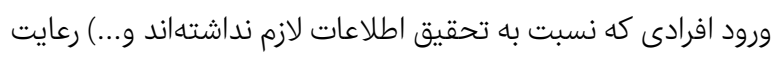

شده است.

جدول 1) تعداد نمونههاى انتخابى مربوط به روستاهاى بخش افزر- دهستان

\begin{tabular}{|c|c|c|c|}
\hline تعداد نمونه & خانوار & جمعيت فوس1 & نام دهيارى \\
\hline Kr & Irr & $k \circ q$ & يير غيب \\
\hline M & gr & r.s & تنكويه سفلى \\
\hline QI & $|V|$ & $\omega \cdot \mu$ & تنگويه عليا \\
\hline m & $q r$ & MrF & جم كور \\
\hline w & 100 & $\mu \omega_{\circ}$ & زاخرو بالا \\
\hline$\mu v$ & 114 & msl & زين آباد زاخرويه \\
\hline$M$ & gr & $r_{01}$ & سرجاه \\
\hline G & $10 \mathrm{~K}$ & $\mu \varepsilon_{0}$ & شارده \\
\hline $9 \Lambda$ & $r \circ \omega$ & $99 \wedge$ & مزرعه يهن \\
\hline$\mu \in \Delta$ & $10 \mu_{0}$ & r & جمع كل \\
\hline
\end{tabular}

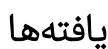

ارزيابى همبستخى ميان متغيرهاى سرمايه اجتماعى: يكى از

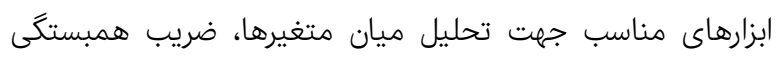

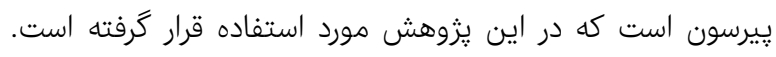

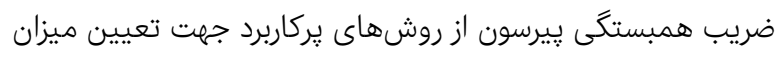

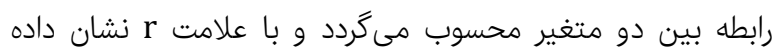

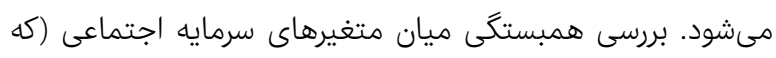

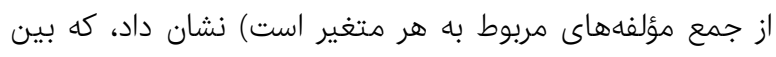

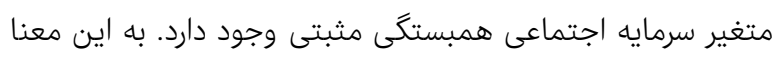

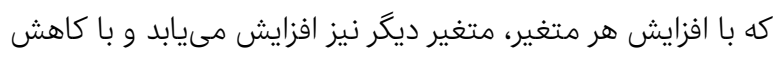

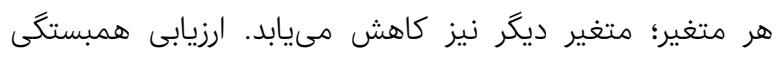

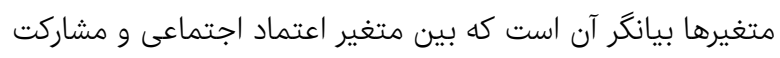

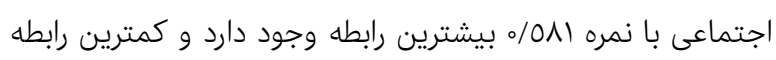

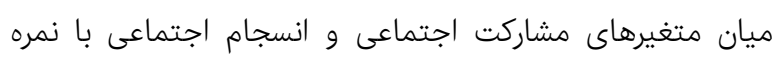

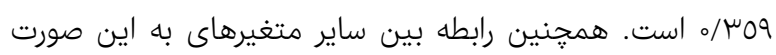

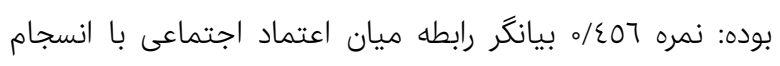

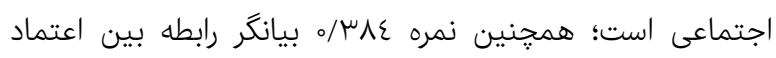
اجتماعى و انسجام اجتماعى است.

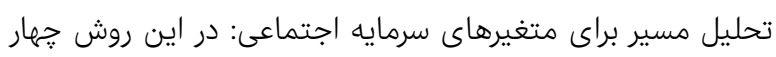

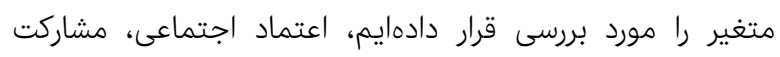

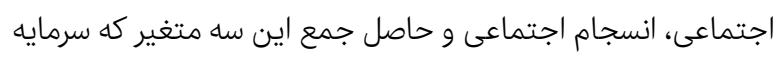

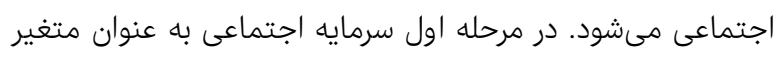

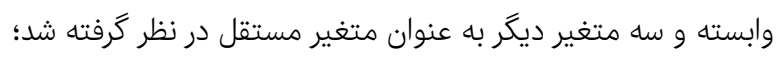


ارزيابى و سنجش وضعيت سرمايه اجتماعى؛ مطالعه موردى روستاهاى دهستان زاخرويه I9

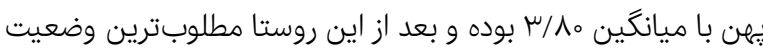

مربوط به روستاهاى جم كور و ييرغيب بوده است (جدول سا).

جدول س) بررسى گويههاى مربوط به متغيرهاى سرمايه اجتماعى و بررسى وضعيت سرمايه اجتماعى در روستاهاى مورد مطالعه

\begin{tabular}{|c|c|c|c|c|}
\hline Sig & $\mathbf{T}$ & $\begin{array}{l}\text { Test } \\
\text { Value }\end{array}$ & ميانگين & $\begin{array}{c}\text { گويههاى مربوط به متغيرهاى } \\
\text { سرمايه اجتماعى }\end{array}$ \\
\hline & & & & اعتماد اجتماعى \\
\hline$\circ \%$ & $18 / 1 \wedge 9$ & $\mu$ & $F / r r$ & اعتماد به مردم روستا \\
\hline$\circ / 001$ & $11 / r_{0} 9$ & $\mu$ & $\mu / \mu \mathrm{V}$ & اعتماد به شوراى اسلامى روستا \\
\hline$\circ \%$ & $-k / \mu \lambda l$ & $\mu$ & r/VA & اعتماد به نهادهاى اجرايى دولتى و \\
\hline$\%$ & $\varepsilon / \Delta V K$ & $\mu$ & $\mu / 01$ & اعتماد به دهيار \\
\hline$\circ$ & $\Lambda / \mu_{0} 7$ & $\mu$ & $\mu / l V$ & اعتماد همسايگان به نظر شما در \\
\hline$\%$ & $1 F / \mu q 9$ & $\mu$ & $\mu / 41$ & اعتماد به نهادهاى اجتماعى روستا \\
\hline$\%$ & $1 Q / \circ \wedge r$ & $\mu$ & $\mathrm{r} / \mathrm{qr}$ & اعتماد به اقوام و خويشاوندان \\
\hline$\circ \%$ & $19 / 9 \circ V$ & $\mu$ & $k / 01$ & مشاركت اجتماعى مشاركت در امور روستا \\
\hline$\circ \%$ & $9 / 009$ & $\mu$ & r/mq & ارتباط با شوراى اسلامى روستا \\
\hline$\% \mu_{0}$ & $k / \& q_{0}$ & $\mu$ & $\mu / \circ V$ & $\begin{array}{c}\text { كمك فكرى و مالى به روستاييان } \\
\text { و دهيارى }\end{array}$ \\
\hline$\% 01$ & Feb-Ir & $\mu$ & r/Vr & مشاركت در يروزههاى عمرانى \\
\hline$\% \circ Y$ & $1 / \wedge k \mu$ & $\mu$ & r/l & شركت در زردهمايىها و جلسات \\
\hline$\circ / \circ F^{\prime}$ & o/VKA & $\mu$ & $\mu / 01$ & عضويت در تعاونىها و تشكلهاى \\
\hline$\circ \%$ & $10 \% 0$ & $\mu$ & $\mu / \Delta q$ & تمايل به يِيگيرى امور و مشكلات \\
\hline$\% 18$ & $|F /| k q$ & $\mu$ & r/AV & 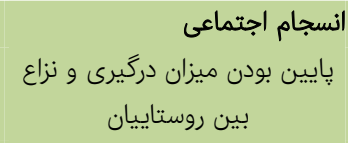 \\
\hline$\% \circ 9$ & IY/IKF & $\mu$ & $\mu / \Lambda 。$ & ميزان همرنكى و يكدلى بين اهالى \\
\hline 。 & $11 / 0 \mathrm{Vq}$ & $\mu$ & $\mu / \varepsilon \mid$ & روابط بين همسايگان و انجام \\
\hline$\%$ & $9 / .00$ & $\mu$ & $\mu / 07$ & حل اختلاف بين مردم به صورت \\
\hline$\% 11$ & Voor & $\mu$ & $\mu / \circ V$ & اهميت دادن به مشكلات ديخران \\
\hline ०/००० & $10 / \wedge \Lambda 1$ & $\mu$ & $\mu / \tau_{0}$ & ميزان (كم) اختلاف سياسى بين \\
\hline & & & & وضعيت سرمايه اجتماعى در \\
\hline$\%$ & V/AIF & $\mu$ & $\mu / \mathcal{F A}^{\prime}$ & ييرغيب \\
\hline$\circ \%$ & s/rাK & $\mu$ & r/ & تنكويه سفلى \\
\hline$\% \circ \Lambda$ & $r / r V I$ & $\mu$ & $m / 。$ & تنكگويه عليا \\
\hline$\circ \%$ & $q / \mu_{\circ} q$ & $\mu$ & $\mu / \Delta \xi$ & جم كور \\
\hline$\circ \%$ & $\circ / \vee \wedge \mu$ & $\mu$ & $\mu / \circ$ & زاخروبالا \\
\hline$\% \% 9$ & $\mu / 19 \mu$ & $\mu$ & $\mu / \mu$ & زينآباد زاخرويه \\
\hline$\% 11$ & $\circ / \mu k I$ & $\mu$ & $\mu /{ }^{\prime} l$ & سرجاه \\
\hline 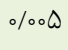 & o/KrA & $\mu$ & $\mu / \circ r$ & شارده \\
\hline$\%$ & $\| / \mathrm{DIT}$ & $\mu$ & щ/^。 & مزرعه يهن \\
\hline
\end{tabular}

متغير مشاركت اجتماعى تنها متغيرى بوده است كه توانسته است

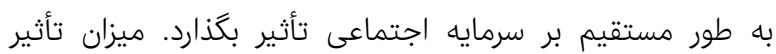

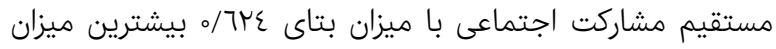

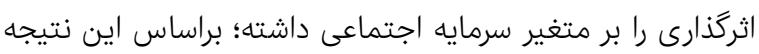

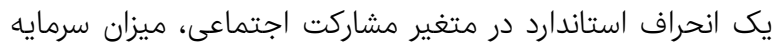

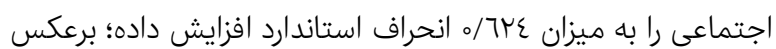

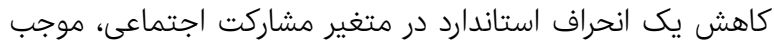

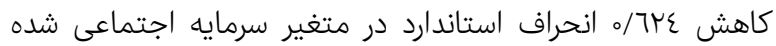

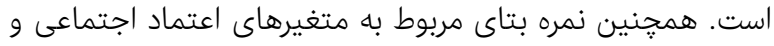

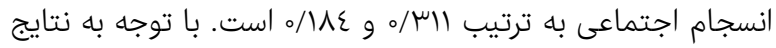

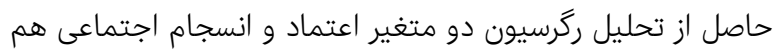

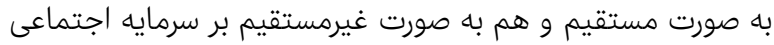
تأثير گذاشتهاند. تأثيرات مستقيم و غيرمستقيم براى متغير اعتماد

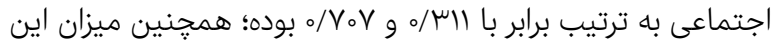

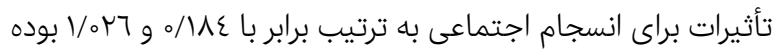

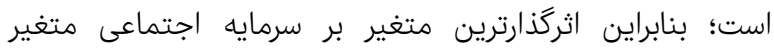

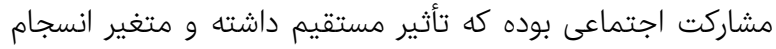
اجتماعى بيشترين اثر غيرمستقيم را بر روى سرمايه اجتماعى داشته

بررسى گويههاى مربوط به متغيرهاى سرمايه اجتماعى و وضعيت

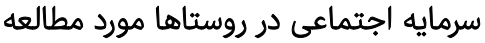

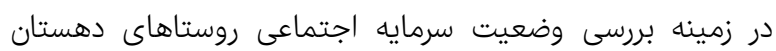

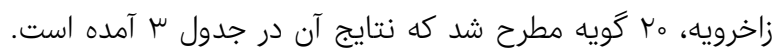

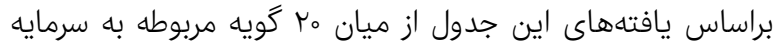
اجتماعى، روستاييان تنها از يكى مورد رضايت كافى نداشئ نداشتهانداند

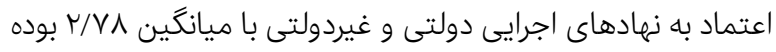

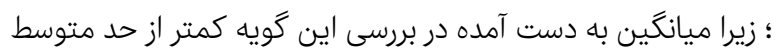

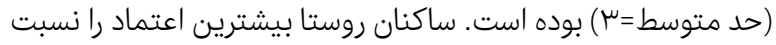

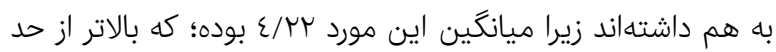

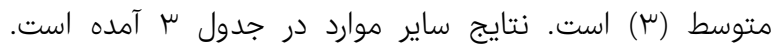
همجنين يافتهها در زمينه وضعيت سرمايه اجتماعى در روستاهاى

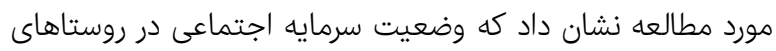

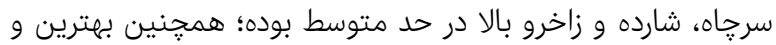
مطلوبترين وضعيت سرمايه اجتماعى مربوط به روستايى مزرعه 
ييشنهادهاى زير جهت افزايش ميزان مشاركت اجتماعى در سطح روستاهاى دهستان زاخرويه مطرح مىشود:

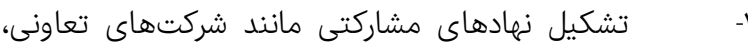

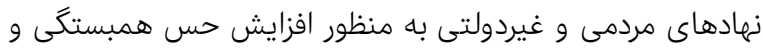

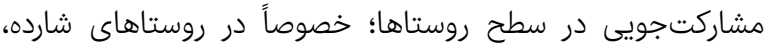

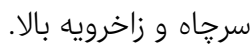

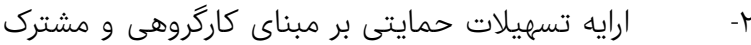

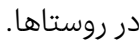

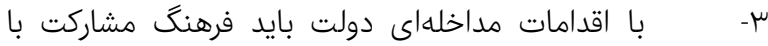
دستخاههاى اجرايى از طريق رسانههاى جمعى به روستاييان آموزش دأش

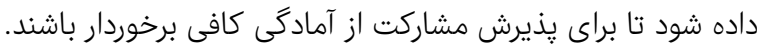

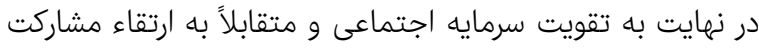

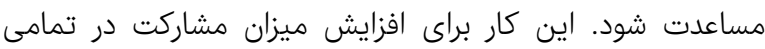
روستاها مىتواند مفيد باشد.

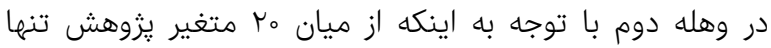

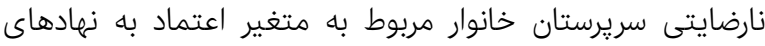

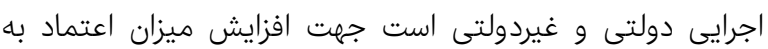

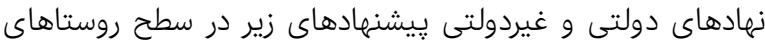

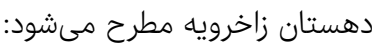

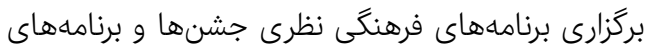
$-1$ مناسبتى (اعياد مذهبى) جهت تقويت شبكه روابط اجتماعى و ايجاد اعتماد بين مردم و دستخاههاى اجرايى.

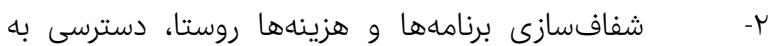
مسئولين و جوابكويى آنها در راستاى ارتقاى اعتماد و مشاركت هرئ

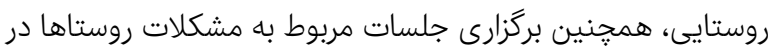

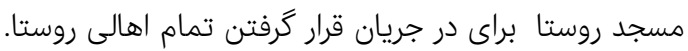

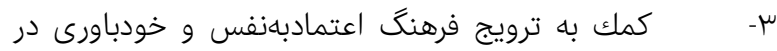
ميان مردم روستا (خصوصاً خانمهاى روستايى) با ايجاد برنامههاى توسعه روستا ع- توزيع اطلاعات بهاطور يكسان در بين روستاييان و

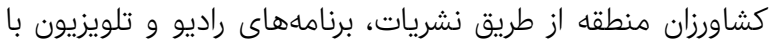
گويش محلى به زبان محلى با هدف جلب اعتماد افراد به همديكر و به مسئولين دولتى، تأكيد بر شاخص اعتى بـ هـاد اجتماعى.

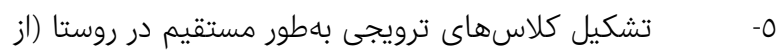
طريق بازديد، يخش فيلم و غيره) جهت آموزشهاى انفرادى و و

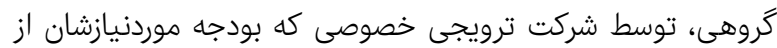

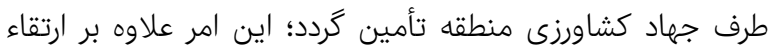

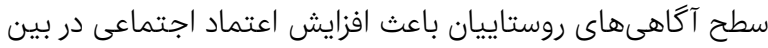
آنها مى شود. همجنين محدوديتهاى يزوهش حاضر وجود مشكلات درد

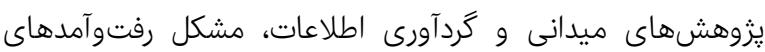

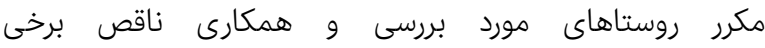

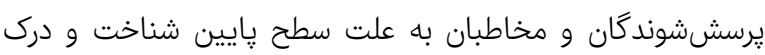
ناكافى نسبت به اهميت موضوع بوندان مخاطبان به عليت
امروزه، يكى از راهبردهاى مورد تأكيد بسيارى از جامعهشناسان و

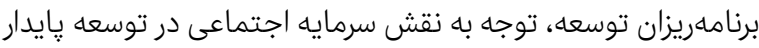

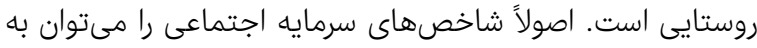

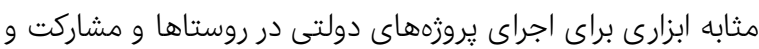

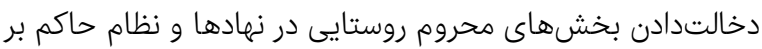

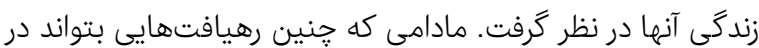
برخى كشورها براى فعاليتهاى در سطح محلى و منطقهاى انگيزه ايجاد كنند، خواهند توانست در طراحى و اجراى برنامهاهـا و سياست

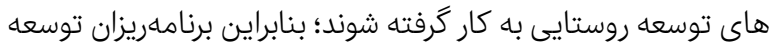

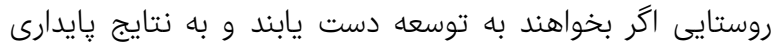
دست يابند، يكى از مهمترين وجوه آن توجه به منابع انسانى بويزه

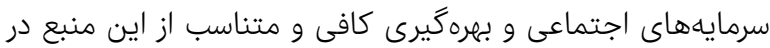
روستاها است. در همين ارتباط در يزوهش حاضر در وهله اول به بررسى ميزان

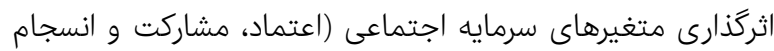
اجتماعى) در مشخصكردن وضعيت سرمايه اجتماعى يرداخته شده

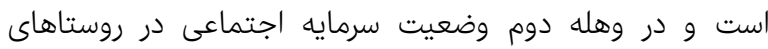
دهستان زاخرويه مشخص شده است. از ميان متغيرهاى سرمايه اجتماعى ميزان اثرگذارى مشاركت اجتماعى بر سرمايه اجتماعى مهنى

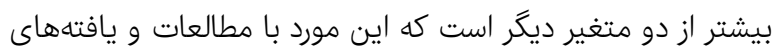

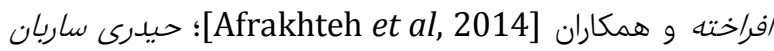

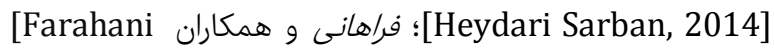
[Toulabi Nejad et al, و طولابى نثزاد و همكاران و هراني et al, 2013] [2018 كاملاً همسو است. همجنين ميزان تأثير مستقيم مشاركت

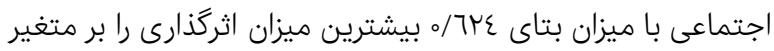

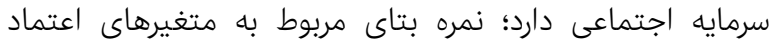

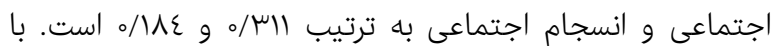
توجه به نتايج حاصل از تحليل رگرسيون دو متغير اعتماد و انسجام

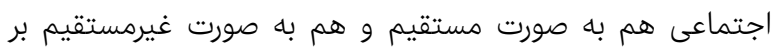
سرمايه اجتماعى تأثير گذاشتهاند. تأثيرات مستقيم و و غيرمستقيم لهيم

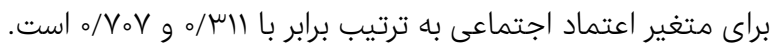

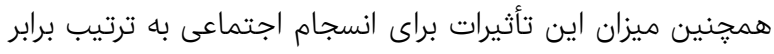

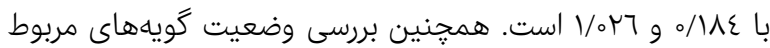

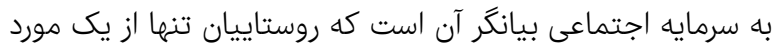

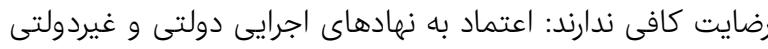

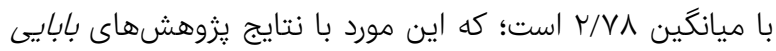
اقدم و همكاران [Babaei Agdam et al, 2015] يكانه و و

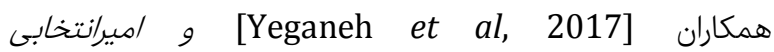
[Amirantakhaby, 2017] هم جهـت است. همجنين سريرستان

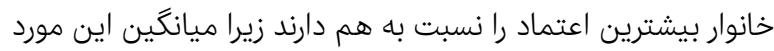

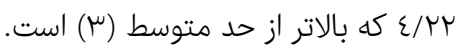

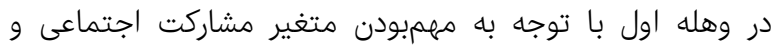
اثرگذارى بيشتر آن نسبت به ساير ابعاد بر سرمايه اجتماعى به مني 
ارزيابى و سنجش وضعيت سرمايه اجتماعى؛ مطالعه موردى روستاهاى دهستان زاخرويه اYس 13(6):873-892.

Farahani H, Abdoli S, Shariati M (2013). Evaluation of the impact of social capital on the development of rural areas with an emphasis on quality of life case study: Mashhad, Maqan, Arak. Journal of Regional Planning. 2(8):67-78. [Persian]

Ghahhari H, Kalantari M, Ghezelbash S (2014). The study of social capital in Zanjan Province. Social Welfare. 13(51):245-281. [Persian]

Hafeznia M R (2013). An introduction to the research method in humanities. Tehran: Samt Press. [Persian] Heydari Sarban V (2014). The effects of social capital effects the rural areas development case study: Meshkinshahr County. Social Development. 8(4):7-28. [Persian]

HeydariSarban V, Majnoony Toutakhane A, Neghabi M (2016). Study and evaluation of the impact of resettlement patterns on social capital changes in earthquake-Stricken villages case study: Varzaqan county earthquake-stricken villages. Journal of Geography and Development. 14(43):51-70. [Persian]

Imani B, Bakhtar, Khoshraftar A (2016). Studying and evaluating effects of social capital on life quality in rural areas. Journal of Rural Research. 6(4):875-894. [Persian] Kakavand E, Ahani S, Zarei F, Hashempour R (2009). Comparative assessment of social investment in neighborhoods by AHP method case study: Qazvin city. Environmental Based Territorial Planning.10(36):25-46. [Persian]

Larson L (2007). Public trust in the PR industry and Its actors. Journal of Communication Management. 11(3): 222-234.

Maleki K, Ghanbari Y, Shayan M, Shafaati A (2015). Measuring coefficient of development ability of big villages of Ravansar. Geographical Researches Quarterly Journal. 30(2):85-102. [Persian]

Mohammadnia F, Timori M, Khanizadeh MA (2018). To study the interaction between social capital and quality of life (both objective and subjective) in the areas of urban planning, case study: 12 Mashhad neighborhood Jahdshhr area. Geographical Planning of Space Quarterly Journal. 8(27):185-200. [Persian]

Nyhan RC (2000). Changing the Paradigm: Trust and Its role in public sector organizations. American Review of Public Administration. 30(1):87-109.

Putnam R (2000). Bowling alone: The collapse and revival of American community. New York: Simon and Schuster. Sabine TK (2004). Trust-Building strategies in interOrganizational negotiations. Journal of Managerial Psychology. 19(6):640-660.

Safaei Pour M, Rahimi Chamkhani A (2018). Critical analysis of sampling designs in human geography research by focusing on selection bias in probability samples. GEORES. 32(4):47-68. [Persian]

Sharifinia Z (2018). Evaluation of social capital in rural settlements case study: Ganj Afrooz village in Babol. New Perspectives on Human Geography. 11(2):313-326. [Persian]

Taleb M, NajafiAsl Z (2011). Doctrines of rural participation trend in Iran. Journal of Ruler Research. 1(2):27-48. [Persian]

ToulabiNejad M, Ghanbari S, Shayan M (2018). Evaluate the impact of social capital on welfare of rural households case study: District Eastern Miyankoh city Poldokhtar. Journal of Geography and Planning. 22(66):163-185. [Persian]

$$
\begin{aligned}
& \text { نتيجه } \\
& \text { مشاركت اجتماعى داراى اثر مستقيم بر سرمايه اجتماعى به ميزان } \\
& \text { عץ7/ه است. مطلوبترين وضعيت سرمايه اجتماعى بهترتيب، } \\
& \text { مربوط به روستاهاى مزرعه يهن، جمكور و يِيرغيب است. } \\
& \text { تشكر و قدردانى: از متصديان مجله وزين تحقيقات جغرافيايى به } \\
& \text { لحاظ راهنمايى و مساعدت ارزنده تشكر و قدردانى به عمل مى آيد. } \\
& \text { تأييديه اخلاقى: موردى از سوى نويسنده گزارش نشده است. } \\
& \text { تعارض منافع: فاقد هرگُنه تعارض منافع است. } \\
& \text { سهم نويسندگان: داداله بهمند (100\%) } \\
& \text { منابع مالى: مقاله به صورت مستقل و با هزينه شخصى نويسنده } \\
& \text { نكَارش شده است. }
\end{aligned}
$$

$$
\text { منابع }
$$

Abusamah A, Aref F (2009). People's participation in community development: A case study in a planned village settlement in Malaysia. World Rural Observation. 1(2):45-54.

Afrakhteh H, Azizi A, Mehralitabar M (2014). The role of social capital on rural development in Chahar Dandah village. Journal of Applied Researches in Geographical Sciences. 14(34):27-45. [Persian]

Amirantakhaby S, Jawan F, Naeem Abadi N (2017). Social capital and sustainability of rural areas in kashmar. Journal of Space Economics and Rural Development. 6(20):79-96. [Persian]

Amado MP, Santos C V, Moura E B, Silva VG (2009). Public Participation in Sustainable Urban Planning. World Academy of Science. Engineering and Technology. 3(5):597-603.

BabaeiAgdam F, VeysiNab F, Yari A, Heydari Sarban V (2015). A study on partnership of settlement in organization of urban distressed areas with an emphasis on social capital: A case study of jajyn Neighborhood Ardabil. Urban Planning Studies. 3(9):65-90. [Persian]

Bahrami R (2018). Assessing the impact of social capital on rural development the case of Sanandaj district villages. Journal of Studies of Human Settlements Planning. 13(3):715-728. [Persian]

Barimani F, Rasti F, Dehani M, Jahantigh R (2018). Analysis of the relationship between social capital and critical security factors: Border settlements in Sistan and Baluchestan province. Geography and Territorial Spatial Arrangement. 8(26):159-178. [Persian]

Barghi H, Zolfaghari AA (2018). Explaining status of entrepreneurship indicators and predicting them in rural residences case study: Ravansar Township. Geographical Researches Quarterly Journal. 33(1):209-223. [Persian] Coleman JS (2007). Foundations of social theory. Sabouri M, translator. Tehran: Ney Press. [Persian]

Dadvar Khani F, Malekan A, Azmi A, Ahmadi R (2013). Comparative study of social capital on rural development upgrade case study: Godvin Rural District, Kangavar County. Journal of Spatial Planning. 3(3):125-144. [Persian]

Ellison NB, Steinfield C, Lampe C (2011). Connection strategies: Social capital implications of Facebook- 
Development. 4(4):75-85. [Persian]

Yeganeh BM, Cheraghi M, Yaripour A (2017). The effects of social capital in economic diversity of rural Households case study: Zarin Dasht Dehestan Darrehshahr county. Journal of Researches and Rural planning. 5(4):1-15. [Persian] World Bank (2008). World development report 2008: Agriculture for development. Washington, DC: World Bank.

Yazdani H, Shams A (2016). The effect of social capital on the environmental behavior of villagers in Marivan City. Journal of Environmental Education and Sustaninable 